\title{
GROUNDWATER LEVEL PREDICTION THROUGH GMS SOFTWARE - CASE STUDY OF KARVAN AREA, IRAN
}

\author{
Mandana Bayat $^{1}$, Saeid Eslamian ${ }^{1,2}$, Gholamreza Shams ${ }^{3}$, Alborz Hajiannia ${ }^{1}$ \\ ${ }^{1}$ Department of Civil Engineering, Najafabad Branch, Islamic Azad University, Najafabad, Iran \\ 'Isfahan University of Technology, Isfahan, Iran \\ ${ }^{3}$ Department of Civil Engineering, Shahrekord University, Shahrekord, Iran
}

Manuscript received: August 5, 2020

Revised version: September 1, 2020

\begin{abstract}
Bayat M., Eslamian S., Shams G., Hajiannia A., 2020. Groundwater level prediction through GMS software - case study of Karvan area, Iran. Quaestiones Geographicae 39(3), Bogucki Wydawnictwo Naukowe, Poznań, pp. 139-145. 6 figs, 4 tables.

ABSTRACT: Iran, being located in arid and semi-arid regions, faces an increase in human demand for water, and the global climate change has led to the excessive use of groundwater. China, India and Iran were ranked from first to third, respectively, in excessive groundwater consumption in 2005. The effects of effective parameters on groundwater recharge such as precipitation, surface recharge and well water harvesting in the Karvan aquifer are assessed. Groundwater flow models have typically been and are being adopted since the beginning of this millennium to better manage groundwater resources. The decrease in groundwater level and the potential environmental hazards thereof have made the researchers here to apply the Groundwater Modelling System (GMS software) in 3D in the subject area. This modelling is calibrated and validated for 86 months at steady and unsteady states. In this study, six scenarios are defined as both an increase and a decrease of $30 \%$ in precipitation, both an increase and a decrease of $30 \%$ in surface recharge, an increase of $10 \%$ in well water harvesting and a decrease of $30 \%$ in well water harvesting. The best scenario is selected for the subject area water management.
\end{abstract}

KEY WORDS: groundwater level, MODFLOW model, GMS software, Karvan aquifer

Corresponding author: Saeid Eslamian saied@cc.iut.ac.ir

\section{Introduction}

With the development of industry, agriculture and the improvement in people's living standards, the demand for water resources is expanding rapidly leading to excessive groundwater consumption with the potential of causing damages to environment. Groundwater numerical simulation is to predict, assess and manage these resources. China, India and Iran are ranked from first to third in excessive consumption of groundwater resources in 2005. On annual bases Iran consumes an average of 5 billion $\mathrm{m}^{3}$ water, which exceeds the available capacity of groundwater layers. This volume of water is equivalent to the volume of water necessary for one-third of the country's total grain production.

GMS is a three-dimensional groundwater simulation software applied in simulating groundwater and solute transport problems associated with groundwater. Compared to other similar software such as MODFLOW, PMWIN, the GMS modules are better than its counterparts due to better user efficiency and 3D visualisation.

The artificial recharge condition of an aquifer in northern China is assessed for different scenarios by applying MODFLOW model. The main factor reducing ground water levels was the irregular water harvesting, in which introduced critical conditions (Wang et al. 2008). MODFLOW 
model in GMS software is adopted to assess the groundwater levels in steady and unsteady states for one year period, and it is found that there exists no significant difference $(p=5 \%)$ between the two states. As to unsteady state modelling for the period more than one year, it is not economically feasible due to the lack of information and provision of sufficient time (Hashemi et al. 2013). Groundwater level control in north China is subject to river water level control, where the hydraulic-hydrogeological conditions and sensitivity analysis of the effective parameters are assessed in GMS software. The best practice there in maintaining groundwater level is to increase the surface recharge (Qiu et al. 2015). The changes in Mahash River Basin of India assessed by modelling it in the MODFLOW software reveal that inability to accurately predict water resource management plans is due to the lack of further information, thus leading to the inability to model unsteady state (Khedri, Pande 2016). MODFLOW model is adopted to evaluate groundwater recharge in Poland by considering atmospheric parameters, soil hydraulic properties and vegetation coverage (Gumuła-Kawęcka et al. 2017). The changes in natural recharge are assessed in the arid region of Ilam by applying MODFLOW software, where the optimal conditions for the region is estimated by changing the mean annual precipitation rate, reducing temperature and improving agricultural conditions (Ghazavi, Ebrahimi 2019). Well water harvesting and climate change is assessed by combining the MODFLOW software with groundwater conditions in a region with various climate and hydrogeology changes, which yields optimal results for better water management in the area (Abraham, Mohan 2019).

GMS software is capable of modelling the aquifer in both steady and unsteady states in the 2D as well as 3D modes by imposing changes in atmospheric parameters and conditions in the area, which leads to better groundwater management in the area.

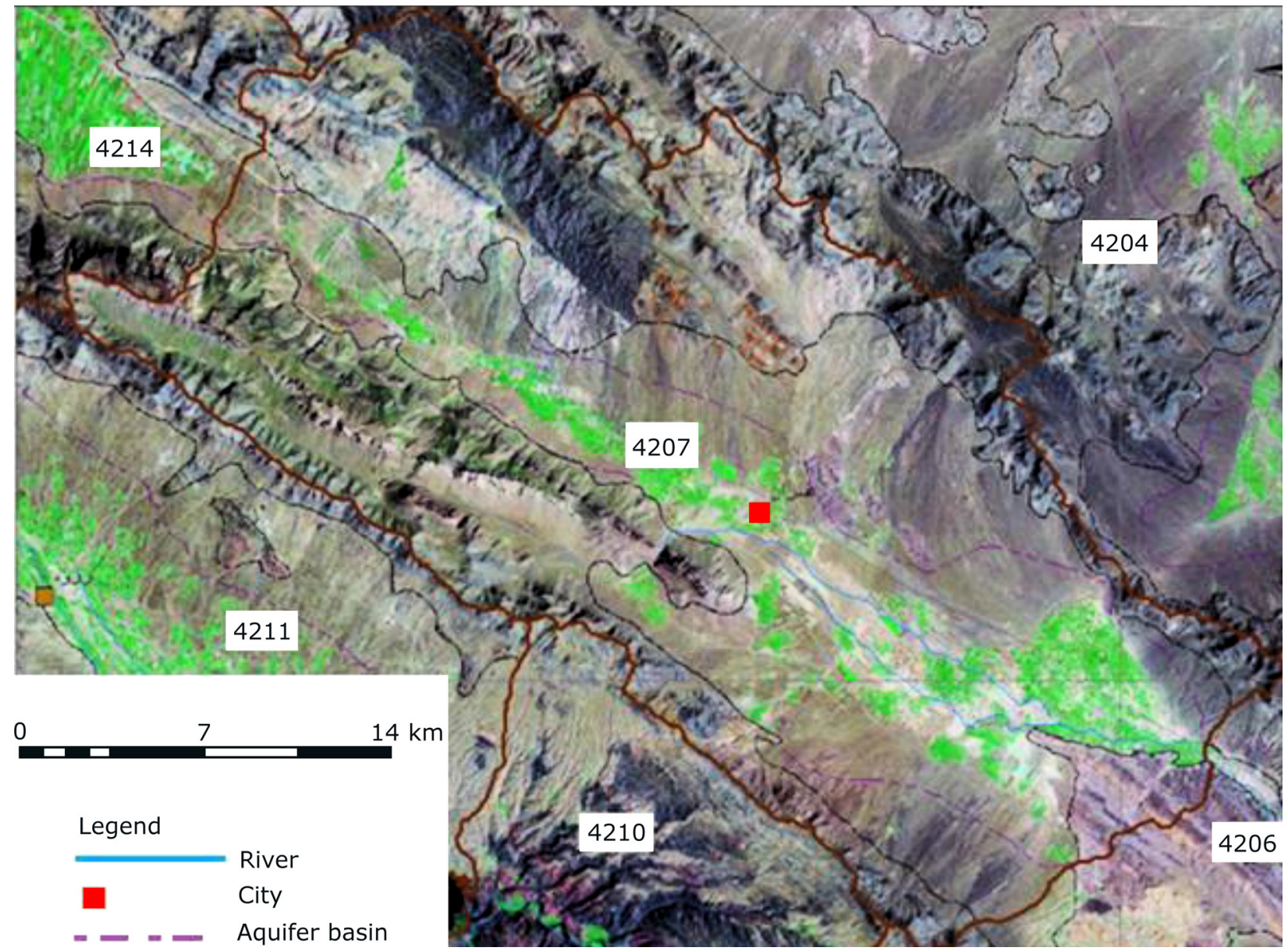

Fig. 1. Geographical states of the subject area. 


\section{Materials and methods}

\section{General and geographical of the subject area}

This area with the code 4207 is a section of the Gavkhnoi Basin, Isfahan Province, Iran (Fig. 1). The geographic status of the area is of $32^{\circ} 10^{\prime}$ to $33^{\circ} 40^{\prime} \mathrm{N}$ and $40^{\circ} 20^{\prime} \mathrm{E}$. The subject area is 225 $\mathrm{km}^{2}$, of which $100 \mathrm{~km}^{2}$ is mountainous and 125 $\mathrm{km}^{2}$ is plain, with an average altitude of about 2,400 m a.s.l. Morghab River is a seasonal river. According to the Koppen classification, the climate of the area is mild semi-arid. Most of the vegetation coverage consist of orchards and cereals such as wheat and barley. The annual mean total long-term precipitation in the altitudes and plains is 328 and $260 \mathrm{~mm}$, respectively, and the annual mean evaporation at altitudes and plains is 2,059 and 2,313 $\mathrm{mm}$, respectively.

The subject aquifer contains 496 groundwater discharge sources, including 401 operating wells with annual discharge of about 31.2 $\mathrm{Mm}^{3}, 61$ subterranean with annual discharge of about $10.7 \mathrm{Mm}^{3}$ and 34 springs with discharge of about 21.6 $\mathrm{Mm}^{3}$ (Table 1). The geographical

Table 1. The description of wells, springs and subterranean.

\begin{tabular}{|l|c|c|c|}
\hline $\begin{array}{c}\text { Consumption } \\
\text { type }\end{array}$ & Numbers & $\begin{array}{c}\text { Discharge } \\
\left(\mathrm{Mm}^{3}\right)\end{array}$ & Percentage \\
\hline Wells & 401 & 31.2 & 49.1 \\
\hline Springs & 34 & 21.6 & 34.0 \\
\hline Subterranean & 61 & 10.7 & 16.9 \\
\hline
\end{tabular}

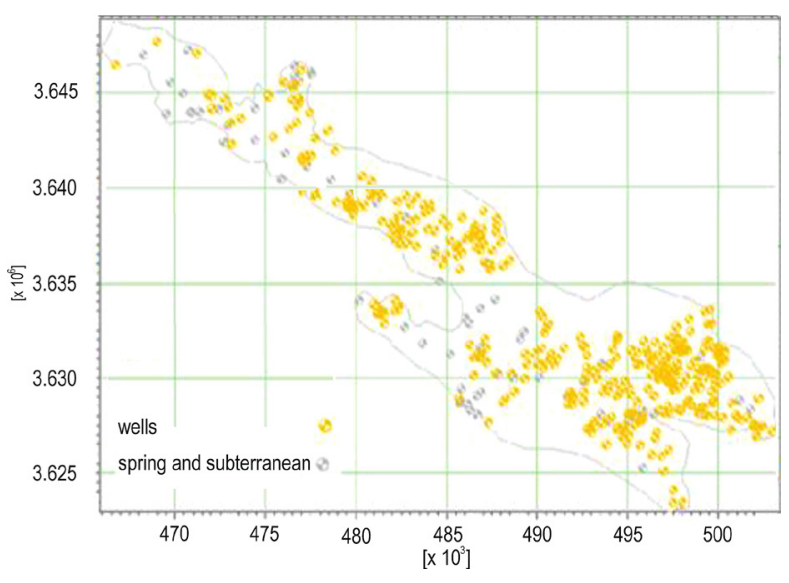

Fig. 2. The geographical distribution of studied wells, spring and subterranean. The $x$-axis represents the aquifer length $\left(\mathrm{p} \mathrm{km}^{-1}\right)$ and the $y$-axis represents the aquifer width $\left(\mathrm{p} \mathrm{km}^{-1}\right)$. distribution of these three categories are shown in Figure 2.

The selected mathematical code in GMS software is of MODFLOW, which is a 3D finite difference model and the nodes are located at the centre of the cell, to which the hydraulic load is assigned. To simulate the subject aquifer, the size of the model grid cells is calculated by sensitivity analysis for all the observed wells with the mean cell size of $400 \times 400 \mathrm{~m}^{2}$. The count of observed wells and exploration wells are 9 and 2, respectively. The water level data of the observation wells measured on monthly basis is applied for model calibration and validation and the exploration well information is applied to estimate the aquifer hydrodynamic coefficients.

\section{Research hypotheses}

- The GMS software is based on finite difference and calculates the hydraulic load at the centre of the cells.

- Estimation (interpolation) of parameter values for each cell centre is essential.

- When modelling the groundwater in GMS, a variety of interpolation techniques are applied to the aquifer parameters at different points and are generalised on the entire aquifer.

\section{Recharge and discharge factors}

The most important aquifer recharge factors consist of the direct infiltration of the Kordolia dam reservoir, precipitation, infiltration of surface floodwater, groundwater entering aquifer and the consumed water return. The aquifer discharge factors consist of water consumed in agricultural, drinking and industry, rainfall runoff, aquifer evaporation and water discharged from wells, springs and aqueducts, the volumes of which are tabulated in Tables 2 and 3.

The details of groundwater balance of the alluvial aquifer are presented in Table 2 revealing that about $15 \%$ of the infiltration of perception is added to the aquifer volume.

With respect to the content of this table, precipitation of $2.6 \%$ of its annual volume is added to the aquifer water. For calculating the aquifer balance (groundwater balance) Eq. 1 is applied (Roscoe Moss Company 1990): 
Table 2. The hydrogeology balance in the subject area.

\begin{tabular}{|c|c|c|c|c|}
\hline Type & Precipitation & Evaporation & Rainfall runoff & Infiltration of precipitation \\
\hline Volumes $\left[\mathrm{Mm}^{3}\right]$ & 214.8 & 133.0 & 40.9 & 40.9 \\
\hline
\end{tabular}

Table 3. The Groundwater balance in the subject area.

\begin{tabular}{|c|c|c|c|c|}
\hline \multicolumn{1}{|c|}{ Type } & $\begin{array}{c}\text { Infiltration of surface } \\
\text { floodwaters }\end{array}$ & Groundwater & $\begin{array}{c}\text { Water consumed in agricultural, } \\
\text { drinking, industry }\end{array}$ & Infiltration of precipitation \\
\hline Input $\left[\mathrm{Mm}^{3}\right]$ & 12.4 & 11.5 & 15.0 & 5.6 \\
\hline Outflow $\left[\mathrm{Mm}^{3}\right]$ & 0.0 & 9.3 & 41.3 & 0.0 \\
\hline
\end{tabular}

$$
\Delta V=\sum_{\text {inlet }}-\sum_{\text {outlet }}=-6.1 \mathrm{Mm}^{3}
$$

(1) - A is the aquifer area $\left(\mathrm{p} \mathrm{m}^{-2}\right)$,

where:

- $\Delta V$ is the water volume change $\left(\mathrm{p} \mathrm{m}^{-3}\right)$,

- $\sum_{\text {inlet }}$ is the total of input volume $\left(\mathrm{p} \mathrm{m}^{-3}\right)$,

- $\quad \sum_{\text {outlet }}$ is the total of output volume $\left(\mathrm{p} \mathrm{m}^{-3}\right)$.

To calculate the changes in water volume in the aquifer Eq. 2 is applied (Roscoe Moss Company 1990):

$$
\Delta V=\mathrm{S}_{\mathrm{y}} \times \mathrm{A} \times \mathrm{h}
$$

where:

- $\Delta V$ is the water volume changes $\left(\mathrm{p} \mathrm{m}^{-3}\right)$,

- $\mathrm{S}_{\mathrm{y}}$ is the aquifer yield coefficient (unitless),
- $h$ is the groundwater level up or down $\left(\mathrm{p} \mathrm{m}^{-1}\right)$. The final volume of the aquifer capacity is $683.8 \mathrm{Mm}^{3}$, with an average annual reduction of $6.1 \mathrm{Mm}^{3}$, that is, $1 \%$. The 3D modelling for Karvan aquifer is performed in steady state for one month which is then calibrated. The unsteady model is constructed and calibrated for 68 months, which is verified for the following 18 months, after which the whole modelling period is verified. The error rate is defined for the calibrated and verified model by observing well water level difference at $1 \mathrm{~m}$ for both states. The period of this modelling is between January 2013 and February 2020, with about seven-year

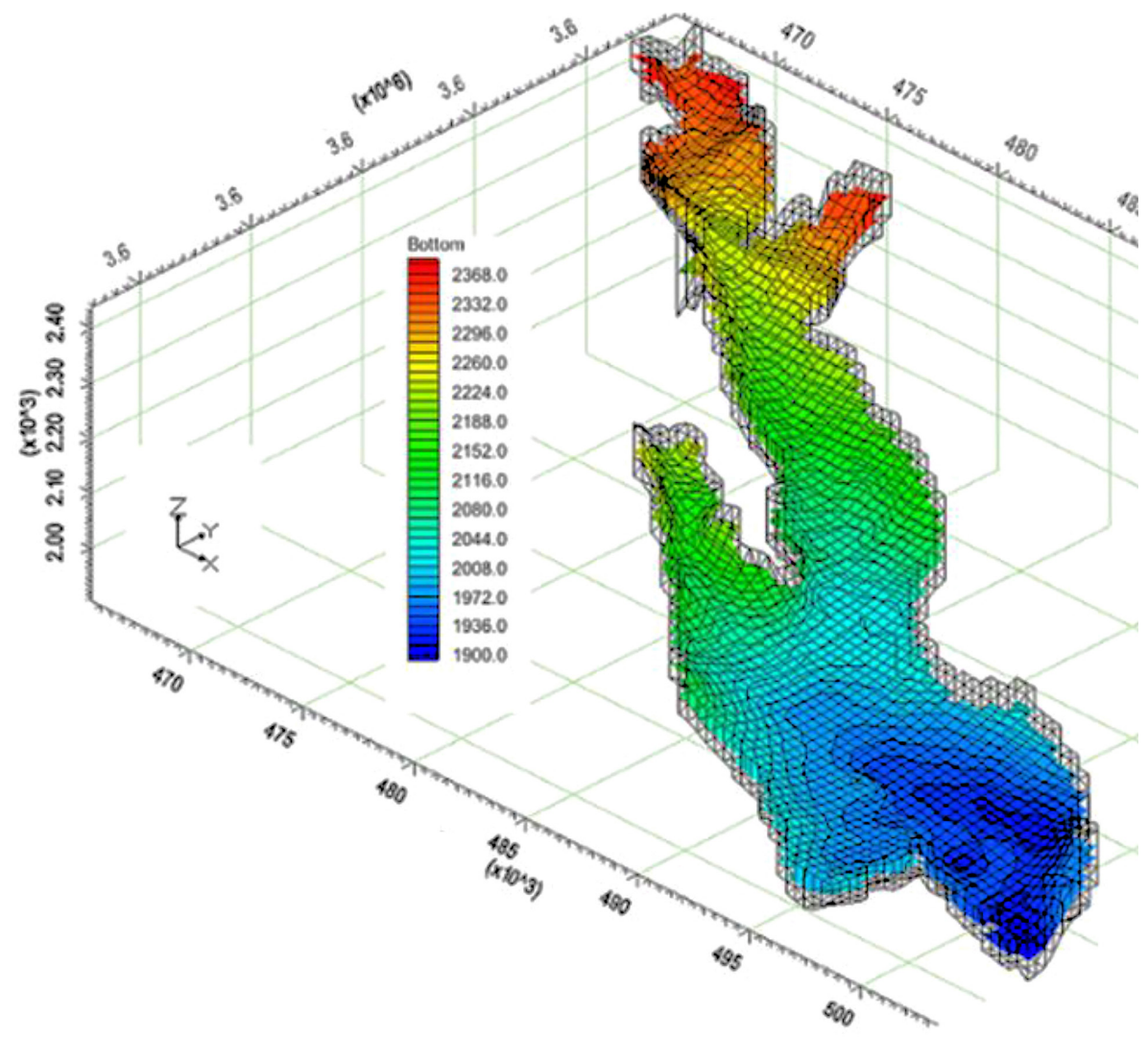

Fig. 3. The number of layers with boundary conditions. 
forecast period (2020-2027). Time steps were considered monthly. The number of layers with boundary conditions are shown in Figure 3.

To calibrate this model in steady and unsteady states, uncertain parameters should be calibrated through pilot or polygon methods to prevent severe statistical bias on a single parameter. The transferability coefficient at the inlet and outlet boundaries of the aquifer and the transferability of the river waterways network are optimised through polygon method by assigning a negative key number to the conceptual model envelopes and with the initial guess at a reasonable minimum and maximum limit. The optimum values of horizontal hydraulic conductivity parameter with 15 pilots, surface recharge of aquifer with 12 pilots, horizontal anisotropy of hydraulic conductivity with 11 pilots and specific yield coefficient with 15 pilots through pilot point method as samples horizontal hydraulic conductivity are shown in Figure 4.

Here, the sensitivity analysis method combined with the calibration step is adopted. The results of the sensitivity analysis of the parameters affecting the calibration of the Karvan aquifer indicate the maximum effect of surface recharge at pilot 7 and the high impact of horizontal hydraulic conductivity at pilot 4 (Fig. 5).

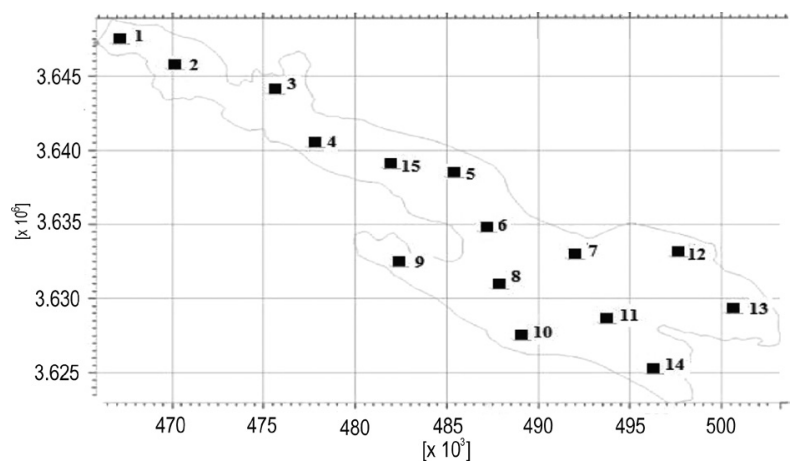

Fig. 4. The key numbers assigned to the pilots to determine surface recharge parameters.

The relative error value of RMS or RMSE is 1.68, indicating high simulation accuracy. To better understand the value of this relative error it should be normalised. To convert RMSE into normalised MSE (NRMSE), Eq. 3 is applied (Mentaschi et al. 2013):

$$
\text { NRMSE }=\frac{\text { RMSE }}{\left(Y_{\max }-Y_{\min }\right)}
$$

where:

- the numerator is the RMSE value and the denominator is the fractional difference between the highest observed well data in the observation wells and the lowest of the same among

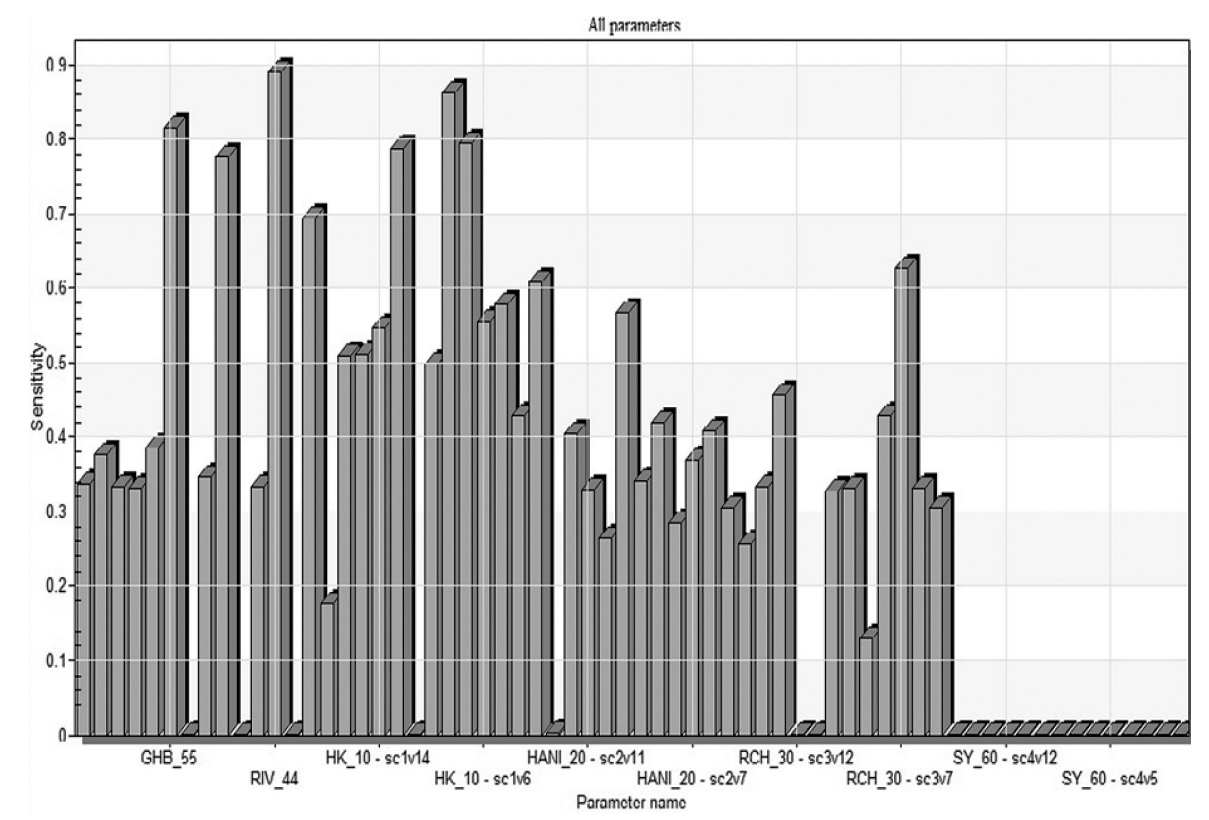

Fig. 5. Comparative sensitivity analysis of all parameters in the unsteady calibration. The $x$-axis represents the parameters name as follows: the transferability coefficient at the inlet and outlet boundaries of the aquifer with GHB. The transferability of the river waterways network with RIV. Horizontal hydraulic conductivity with HK. Surface recharge of aquifer with RCH. Horizontal anisotropy of hydraulic conductivity with HANI.

Specific yield with SY. The $y$-axis represents the sensitivity analysis of aquifer for these parameters. 


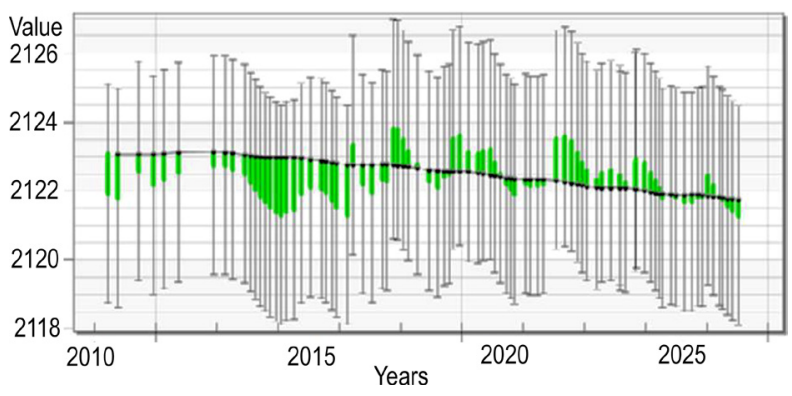

Fig. 6. A - the location of observation and exploration wells. B - the error rate for the values of the computational data in the verification phase - Observation well \#2; the $x$-axis represents time $\left(\mathrm{p} \mathrm{a}^{-1}\right)$ and the $y$-axis represents groundwater level in different wells $\left(\mathrm{p} \mathrm{m}^{-1}\right)$.

all observation wells at $172.06 \mathrm{~m}$ yielding the value 0.0097 ; because it is less than 0.1 , the modelling is ideal.

The model is validated for the initial 18 months, and for the total modelling period (86 months) for observation wells is performed as shown, for example, in well \#2 in Figure 6.

\section{Results and Discussion - scenarios run for modelling through GMS}

The capacity of the Karvan aquifer is 683.8 $\mathrm{Mm}^{3}$, which is being reduced in recent years leading to critical conditions, which makes its modelling, for prediction a period of 86 months a must. The groundwater level changes in the aquifer for different scenarios with $\mathrm{dh}\left(\mathrm{p} \mathrm{m}^{-1}\right)$, aquifer volume changes with $\mathrm{dV}\left(\mathrm{Mm}^{3}\right)$ and percentage of aquifer volume changes with $\% \mathrm{dV}$ are presented in Table 4 . The greatest increase in aquifer capacity is a $30 \%$ rise in precipitation. The greatest decrease in aquifer capacity is a $30 \%$ decline in surface recharge. The results of different scenarios are tabulated in Table 4 . The run scenarios consist of:

Table 4. Groundwater level variations of the Karvan area for the defined scenarios.

\begin{tabular}{|l|r|r|r|}
\hline \multicolumn{1}{|c|}{ Range } & dh $[\mathrm{m}]$ & $\mathrm{dV}\left[\mathrm{Mm}^{3}\right]$ & $\% \mathrm{dV}$ \\
\hline $\mathrm{RCH},-30 \%$ & -0.430 & -49.34 & -7.21 \\
\hline $\mathrm{RCH},+30 \%$ & 0.182 & 20.88 & 3.05 \\
\hline $\mathrm{P},+30 \%$ & 0.573 & 65.75 & 9.62 \\
\hline $\mathrm{P},-30 \%$ & -0.207 & -23.75 & -3.48 \\
\hline Wells, $-30 \%$ & 0.373 & 42.80 & 6.26 \\
\hline Wells, $+10 \%$ & -0.122 & -13.99 & -2.05 \\
\hline
\end{tabular}

1. Increase and decrease at $30 \%$ at surface recharge,

2. Increase and decrease at $30 \%$ at annual precipitation average,

3. A $30 \%$ decrease in well water harvesting and a $10 \%$ increase in the same.

According to the UNIC index, Iran consumes more than $70 \%$ of its total renewable water resources which has led to a severe water crisis condition. The per capita renewable water consumption according to the Falkenmark Index in critical conditions of Iran is 1,000 to $1,700 \mathrm{~m}^{3} \mathrm{a}^{-1}$. By considering the $20 \%$ decrease in the average annual precipitation in this area and the negative water balance therein, storage and management of surface water and groundwater is vital. Due to climate change, consumption control methods and artificial recharge in this aquifer would lead to water storage and be contributive in overcoming the water crisis.

\section{Conclusion}

Iran consumes an average of 5 billion $\mathrm{m}^{3}$ of water per year, more than the capacity of the groundwater volume. Given this situation, the Karvan aquifer is modelled as a case study, calibrated and validated for 86 months. The results of the simulations here on climate change, water consumption control methods and methods of artificial recharge to improve a situation and water storage in the aquifer are briefed as follows:

- The Karvan aquifer due to extreme and excessive water harvesting and climate change has lost stability and follows a rapid declining trend. If groundwater harvesting continues in this manner, in addition to lowering groundwater reserves, the quality of the remaining groundwater would decrease as well. This phenomenon would lead to more serious problems in all aspects of the region.

- By applying a calibrated model, it is found that a reduction of almost $30 \%$ in well water harvesting leads to an increase in mean groundwater level by $37 \mathrm{~cm}$ and an increase of $10 \%$ in well water harvesting; the mean groundwater level will decrease about $12 \mathrm{~cm}$.

- Surface water results for this period indicate that water levels in most parts of the aquifer 
follow a uniform decreasing pattern, indicating if the wells are discharged and recharged as in the previous years, most observational wells face a drastic drop in water level.

- Due the dispersion of water subject to harvest in the subject area, a change in the harvest rate would change the groundwater level in the entire aquifer in a uniform manner.

- By applying a calibrated model, it is found that an increase of $30 \%$ surface recharge could increase the mean water level of aquifer by 18 $\mathrm{cm}$ and a $30 \%$ decrease would yield a $43 \mathrm{~cm}$ decrease in the mean groundwater level, thus a significant negative effect on aquifer.

- In one scenario, using the calibrated model, a $30 \%$ average of precipitation increase could increase the mean groundwater level of the aquifer by a $57 \mathrm{~cm}$, whereas a $30 \%$ average precipitation decrease could decrease the mean groundwater level of the aquifer by 20 $\mathrm{cm}$, indicating that this volume will have a negative effect on the aquifer.

- The model developed here has sufficient accuracy and validity, and is recommended to be applied in aquifer management.

According to the scenarios studied here, among the changes through artificial recharge, precipitation and well water harvesting, precipitation is the most effective procedure in aquifer water management.

\section{Acknowledgments}

The authors would like to thank the reviewers for the constructive feedback.

\section{Author's contribution}

Mandana Bayat - 60\%, Saeid Eslamian - 20\%, Gholamreza Shams - 10\%, Alborz Hajiannia - 10\%.

\section{References}

Abraham M., Mohan S., 2019. Effective of check dam and percolation pond with percolation wells for artificial groundwater recharge using groundwater models. Water Supply 19(7): 2107-2115.

Ghazavi R., Ebrahimi H., 2019. Predicting the impacts of climate change on groundwater recharge in an arid environment using modeling approach. International Journal of Climate Change Strategies and Management 11(1): 219224. DOI 10.1108/IJCCSM-04-2017-0085.

Gumuła-Kawęcka A., Szymkiewicz A., Angulo-Jaramillo R., Šimůnek J., Jaworska-Szulc B., Pruszkowska-Caceres M., Gorczewska-Langner W., Leterme B., Jacques D., 2017. Numerical simulation of infiltration and groundwater recharge using the Hydrus for Modflow package and the BEST model of soil hydraulic properties. Geophysical Research Abstracts 19 EGU2017-1514.

Hashemi H., Berndtsson R., Kompani-Zare M., Persson M., 2013. Natural vs. artificial groundwater recharge, quantification through inverse modeling. Hydrology and Earth System Sciences 17: 637-650. DOI 10.5194/hess-17-6372013.

Khedri S.F.R., Pande Ch., 2016. Ground water flow modelling for calibrating steady state using MODFLOW software: A case study of Mahesh River basin, India. Modelling Earth Systems and Environment 2: 39. DOI 10.1007/ s40808-015-0049-7.

Mentaschi L., Besio G., Cassola F., Mazzino A., 2013. Why NRMSE is not completely reliable for forecast/hindcast model test performances. Geophysical Research Abstracts 15 EGU2013-7059.

Qiu S., Liang X., Xiao C., Huang H., Fang Z., Lv F., 2015. Numerical simulation of groundwater flow in a river valley basin in Jilin urban area, China. Water 7(10): 5768-5787. DOI $10.3390 / w 7105768$.

Roscoe Moss Company, 1990. Handbook of groundwater development. A Willy-International Publication, Los Angeles, California.

Wang S., Shao J., Song X., Zhang Y., Huo Z., Zhou X., 2008. Application of MODFLOW and geographical information system to groundwater flow simulation in North China Plain, China. Environmental Geology 55: 1449-1462. DOI 10.1007/s00254-007-1095-x. 